Article

\title{
Quantification and Characterisation of Pre-Production Pellet Pollution in the Avon-Heathcote Estuary/Ihutai, Aotearoa-New Zealand
}

\author{
Emma Caitlin Hunter ${ }^{1}$, , Raquelle de Vine ${ }^{2}$, Olga Pantos ${ }^{3}$, Phil Clunies-Ross ${ }^{2}$, Fraser Doake ${ }^{3}$, \\ Hayden Masterton ${ }^{3}$ and Robert A. Briers ${ }^{1}$ (D)
}

check for

updates

Citation: Hunter, E.C.; de Vine, R.; Pantos, O.; Clunies-Ross, P.; Doake,

F.; Masterton, H.; Briers, R.A.

Quantification and Characterisation of Pre-Production Pellet Pollution in the Avon-Heathcote Estuary/Ihutai, Aotearoa-New Zealand. Microplastics 2022, 1, 67-84. https://doi.org/ $10.3390 /$ microplastics1010005

Academic Editor:

Nicolas Kalogerakis

Received: 1 December 2021

Accepted: 13 January 2022

Published: 17 January 2022

Publisher's Note: MDPI stays neutral with regard to jurisdictional claims in published maps and institutional affiliations.

Copyright: (C) 2022 by the authors. Licensee MDPI, Basel, Switzerland. This article is an open access article distributed under the terms and conditions of the Creative Commons Attribution (CC BY) license (https:// creativecommons.org/licenses/by/ $4.0 /)$.
1 School of Applied Sciences, Edinburgh Napier University, Edinburgh EH11 4BN, UK; r.briers@napier.ac.uk

2 Algalita Marine Research and Education South Pacific Trust, Christchurch 0941, New Zealand; raquelle@algalita.org (R.d.V.); phil.clunies.ross@gmail.com (P.C.-R.)

3 Institute of Environmental Science and Research Ltd., 27 Creyke Road, Ilam, Christchurch 8041, New Zealand; olga.pantos@esr.cri.nz (O.P.); fraser.doake@esr.cri.nz (F.D.); hayden.masterton@pg.canterbury.ac.nz (H.M.)

* Correspondence: emmacaitlinhunter@gmail.com

\begin{abstract}
Plastic pollution is threatening aquatic ecosystems and wildlife. Understanding the characteristics and extent of plastic pollution is the first step towards improving management and therefore the environmental impacts. Pre-production pellets are used in the manufacture of a range of consumer items. The Avon-Heathcote Estuary/Ihutai in Aotearoa-New Zealand, an important wildlife habitat, was assessed for the presence and characteristics of pre-production pellets. Following a visual survey of the estuary's perimeter to establish overall levels, seven accumulation hotspots were identified, and surveyed in more detail. The enumeration and characterisation of pellet colour, size, morphology, degree of weathering and polymer type was undertaken. A total of 3819 pellets were identified, with pellets present at all sites. The pellets were predominantly clear $(86 \%), 3 \mathrm{~mm}$ in size $(54 \%)$, cylindrical in shape $(62 \%)$, showed moderate weathering $(41 \%)$ and were made of low-density polyethylene (LDPE) (53\%). Pellet abundance and characteristics varied between sites. Accumulation and abundance may be influenced by river inflows along which plastic manufacturers are located, weather conditions, locality to stormwater outlets and pellet characteristics. Pellet pollution is a notable problem in the Avon-Heathcote Estuary/Ihutai and it highlights the need to better understand the sources and improve best management practices.
\end{abstract}

Keywords: estuary; best management practices; microplastics; pellets; plastic pollution; polyethylene

\section{Introduction}

Since the 1940s-1950s, plastic has been mass produced to create a range of everyday items $[1,2]$ that have greatly benefitted society. Its lightweight and durable design matched with a low price point [3] has seen plastic's popularity grow, with 368 million tonnes of plastic produced in 2019, an increase of over 20 million tonnes since 2017 [4]. A lack of effective end-of-life management and plastic's resistance to natural degradation processes has led to its accumulation in the environment as debris [5]. Globally, around 79\% of used plastic products are discarded into landfill or the environment, 12\% are incinerated and only $9 \%$ are recycled [6]. Once in the environment, plastic debris is susceptible to long distance travel via wind and currents, assisted by its low density and high resilience. If plastic is deposited in sediment, it can persist for hundreds to thousands of years [7].

In addition to the aesthetic impact that plastic pollution has, there are established and growing concerns over the impacts it has on the health of ecosystems, with plastic now being added to the United Nations' Basel Convention on the Control of Transboundary Movements of Hazardous Wastes and their Disposal, effective January 2021 [8]. Plastic ingestion has been recorded in a range of aquatic species across different habitats and feeding 
strategies, such as deposit feeders (Chironomus spp.) [9], sea turtles [10-12], seabirds [13-15] and marine mammals [16]. Ingestion can cause obstruction of the digestive tract, leading to death by starvation due to false satiation $[17,18]$. In addition, plastics can adsorb persistent organic pollutants [19] and heavy metals [20], which may, in turn, be harmful when swallowed [21]. Plastics also provide a vector of transport for invasive species and potential pathogens [22,23].

The ingestion of microplastics by aquatic organisms and wildlife has been documented for over a decade [24]. Microplastics are currently defined as plastic particles less than $5 \mathrm{~mm}$ in size [25] and can be broadly categorised into either primary or secondary microplastics. Primary microplastics have been intentionally created to be less than $5 \mathrm{~mm}$ in size [25], as opposed to secondary microplastics, which are the fragmentation products resulting from processes such as weathering and biological and UV degradation [26].

The bulk of the research into microplastic accumulation has focused on the marine environment, and data from estuarine and freshwater environments are lacking in comparison [27]. Around 70-80\% of plastic debris in the marine environment has land-based sources [28]. A key medium of transport of plastic debris from land to ocean is freshwater systems with influence from sewage outfalls [29] and flooding events [30]. The estuarine environment is an important area to study, as it could indicate the mechanisms involved in plastic transportation as the interface between freshwater systems and the open ocean.

Studies have indicated that pre-production plastic pellets are a pollutant in freshwater environments and shorelines [17,31]. During the manufacture of plastic products, virgin pre-production plastic pellets are melted and formed into the desired plastic item, often requiring thousands of pellets to create a single item. Between 58 and 70.6 million tonnes of plastic pellets are produced in Europe each year [32], with the majority used to produce packaging [2]. Chemical additives such as thermal stabilisers, colourants, anti-oxidants, softeners and biocides are often included in this process depending on the end product $[2,16]$, which adds to their pollutant potential. The routes of entry of pellets to the environment include accidental loss during transport, human handling error and run-off from manufacturing plants [33-35]. Like other microplastics, pre-production pellets pose a chemical and physical threat to wildlife by being mistaken for prey items, being unintentionally ingested via filter-feeding [36] or indirectly ingested through the food chain [16]. Pellet pollution in Aotearoa-New Zealand (A-NZ) has been documented since the 1970s [37]. Notably, in 2011, 150 tonnes of pellets were lost from the MV Rena container ship off the coast of Tauranga during a stranding event. In 2017, over 300,000 tonnes of virgin resin for manufacture were imported into the country [38].

To reduce plastic pollution in the environment, effective management strategies should be put in place. A lack of product labelling [39] and secondary microplastics appearing as a fragment of the original product [40] make the origin of plastic pollution difficult to highlight. However, pellets are property of the plastics industry and therefore the responsibility for their presence in the environment can be assigned accordingly. Information gained by identifying accumulation hotspots and the characterisation of pellets could help inform best management practices used by the local plastics industry with positive implications for the environment and wildlife. For example, Operation Clean Sweep (OCS) is an international programme that has been adopted by 23 countries worldwide, including A-NZ. Its goal is to help the plastics industry achieve zero pre-production plastic loss and pollution of the environment. Algalita Marine Research Foundation (AMRF) found a reduction in pellet loss at seven plastic industries in California after the adoption of Best Management Practices (BMPs) encouraged by OCS [41]. The Industry Association in A-NZ, Plastics NZ, aims to "maximise the development, growth and success of plastics-based technology in an economically, socially and environmentally responsible manner" [42]. They currently have 67 members who have adopted OCS's BMP to keep plastics out of the environment. Eight of these companies are based in the inner Ōtautahi/Christchurch area [43] (Figure 1). 


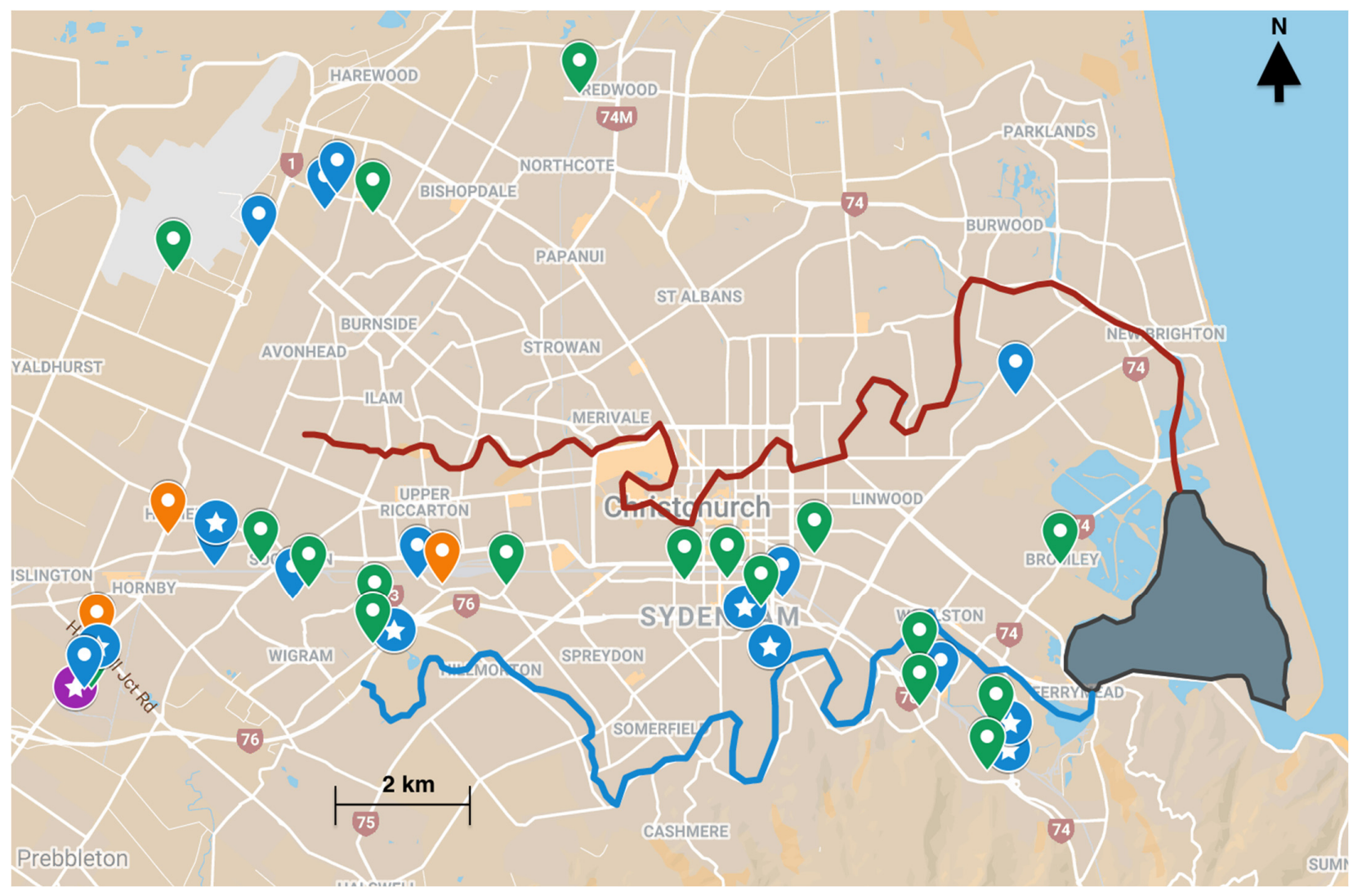

Figure 1. Map of study area and plastics industry around Ōtautahi/Christchurch. Created using Google Maps "My Maps" software. The Avon-Heathcote Estuary/Ihutai is shaded grey. The Ōtākaro/Avon River is lined in red and the Ōpāwaho/Heathcote River is lined in blue. Blue markers with a white dot represent plastic manufacturers that are members of Plastic NZ. Blue markers with a white star represent plastic manufacturers that are members of Plastics NZ and that have adopted best practices under Operation Clean Sweep. Orange markers with a white dot represent plastic suppliers or distributors that are members of Plastics NZ. The purple marker with a star represents a plastic recycler that is a member of Plastics NZ and has adopted best practice under Operation Clean Sweep. Green markers with a white dot represent plastic manufacturers/fabricators/distributors that are not members of Plastics NZ. Correct as of December 2021 using publicly available information.

Plastic debris has long been documented on the shorelines of A-NZ [37,44,45], being attributed to the proximity of urban areas [44,45] with influences from stormwater [37] and wastewater [46]. This study aimed to assess the extent of pellet abundance in the Avon-Heathcote Estuary/Ihutai. The first objective was to identify whether pre-production pellets, a primary microplastic, were present in the estuary, and the extent, pattern and level of pollution. In addition, the hotspots of pellet accumulation in the estuary were identified and the predominant characteristics of the pellets were recorded to infer potential point sources. Microplastic presence in aquatic ecosystems is frequently correlated with areas of high industrial activity $[39,47,48]$; thus, given the estuary's close proximity to Otautahi/Christchurch, the second largest city in A-NZ, with a substantial plastics industry (Figure 1), pellet contamination was not only expected, but predicted to be of a relatively high level.

\section{Materials and Methods}

\subsection{Study System}

The Avon-Heathcote Estuary/Ihutai $\left(43^{\circ} 32^{\prime} 30^{\prime \prime} \mathrm{S}, 172^{\circ} 43^{\prime} 30^{\prime \prime} \mathrm{E}\right)$ is located $12 \mathrm{~km}$ from Ōtautahi/Christchurch city centre. The estuary is fed by two rivers: the Ōtākaro/Avon and the Ōpāwaho /Heathcote, and one canal: Linwood Avenue Canal, draining into the 
Pacific Ocean. The estuary is made up of approximately 880 ha of intertidal mud flats and salt marshes [49].

These habitats, along with surrounding areas of grassland, wetland reserves and the oxidation ponds at the municipal wastewater treatment plant, support more than 30,000 birds at peak times of the year [50]. The estuary forms part of the East Asian-Australasian Flyway for migratory bird species [50] and supports over 10 species of wetland bird at $1 \%$ of individuals in a biogeographic population, thus fulfilling the Ramsar Convention criterion determined by Wetland International [51]. The estuary is also of historical and cultural significance, with human settlement having occurred 600 years ago, with Māori tribes Waitaha, Ngāti Mamoe and Ngāi Tahu utilising the area for settlement and food gathering [52]. When the Europeans arrived, the waterway was a key site for trade and as a port of entry [53]. Today, the estuary supports recreational activities such as windsurfing and sailing, and small groups continue to gather shellfish such as the estuarine cockle/Tuaki (Astrovenus stuchburyi) for consumption [53].

\subsection{Rapid Estuary Assessment}

At low tide, the perimeter of the $8 \mathrm{~km}^{2}$ Avon-Heathcote Estuary/Ihutai was walked to determine the presence of pellets to gain a "snapshot" of relative abundance, spatial location and potential accumulation hotspots. The tidal range of the estuary is from $2.1 \mathrm{~m}$ at spring tides to $1.1 \mathrm{~m}$ at neap tides (approximately). Clunies-Ross et al. [45] recorded low levels of microplastics using a sampling regime that focused on the strandline, but observed large amounts of plastic waste accumulated on the estuary bank, therefore this area was the focus of the rapid estuary assessment. Using the Epicollect5 data collection application (https: / five.epicollect.net accessed on 21 July 2021), when a pellet was observed, the GPS coordinates were recorded. In addition, a $25 \times 25 \mathrm{~cm}$ quadrat was placed where the pellet was spotted and a ranked general level of surface pellet abundance determined (LOW: 5-10 pellets, MEDIUM: 10-20, HIGH: 20+).

\subsection{Site Selection}

The hotspot information gathered in the rapid estuary assessment was mapped using QGIS software (Version 3.10.9 LTR, QGIS.org [54]) and the seven sites with the largest clusters of hotspots were identified for more detailed sampling of the sediment. The seven hotspot sites were also grouped according to geographical location (southwest, southeast or east) to assess the influence of wind direction for the purpose of analysis.

\subsection{Sediment Sampling}

All seven sites were visited across a two-day period (8th October and 9th October 2020) to reduce the impact of differences in time and weather conditions. A $50 \mathrm{~m}$ transect was measured out at each site and samples were collected along the transect at $10 \mathrm{~m}$ intervals. A $25 \mathrm{~cm} \times 25 \mathrm{~cm}$ quadrat was placed on the substrate at the locations of the $10 \mathrm{~m}$ integers. A trowel was used to remove the top $5 \mathrm{~cm}$ of sediment, as microplastic deposition tends to be limited to the upper layers of the sediment $(3.5 \pm 0.5 \mathrm{~cm})$ [55]. Where the quadrat was placed on a hard substrate that could not be extracted (e.g., rock), the percentage area and the extent to which it reduced the overall sediment volume was noted for consideration in later density calculations. Visuals of the sample site transects and quadrats are available in Table S1. To reduce the sample volume for ease of later analysis, density separation was used to separate buoyant pellets [56] from the sand. The extracted sample was placed in a metal bucket of seawater and floating debris was collected using a $2 \mathrm{~mm}$ mesh sieve. The sieving method used may have underestimated the abundance of pellets that are smaller than $2 \mathrm{~mm}$, but visual examination of the material that passed through the sieve did not show any evidence of smaller pellets being present. In addition, pre-production pellets tend to be larger than $2 \mathrm{~mm}$ in diameter [57]. The sieved material was transferred to labelled zip lock bags for transport. 


\subsection{Sample Analysis/Pellet Extraction}

The samples were dried on metal trays at room temperature overnight and then the sediment was passed through $4.75 \mathrm{~mm}$ or $2 \mathrm{~mm}$ sieves to remove excess organic matter, making identification of the pellets easier. The pellets were visually identified using the criteria set out by Turner et al. [57]: smooth surface, lentil/disc/cylindrical shape, usually with a depression evident on one side of the pellet. The use of a $\times 2$ magnifying glass and physical manipulation using forceps, as recommended by Lusher et al. [58], were used to rule out organic material that resembled pellets. The extracted pellets were stored in labelled glass jars (one per sample).

The pellet density (pellet $\mathrm{m}^{-3}$ of sediment) was calculated and each pellet categorised to the closest secondary colour level (red, orange, yellow, green, blue, violet) in addition to black, white and clear, as advised by Lusher et al. [58]. To account for discolouration due to weathering, any coloured pellet was held up to a light. If the light shone through, the pellet was classified as clear. Pellet extraction was deemed complete for a sample after a period of five minutes during which no pellets were identified.

\subsection{Pellet Characterisation}

To help identify possible point sources of pellets, their dispersal potential and longevity, the extracted pellets were classified by size, shape and degree of weathering. A subsample approach was used for characterisation [59]. The five samples collected for each site were combined, mixed and $25 \%$ of the total pellets transferred into a petri dish for analysis. In total, 956 pellets were characterised. Under a Philips $5.5 \mathrm{~W}$ LED light, the pellets were measured to the nearest $\mathrm{mm}$ across the widest point and the shape was characterised to be either cylindrical, spherical, lenticular or rectangular (Figure 2). Cylindrical was determined if the pellet had linear edges connecting two circular faces, spherical if no edges were present, lenticular if the edges met on one plane and rectangular if the edges met at a $90^{\circ}$ angle (Figure 2a). Each pellet was assigned a weathering score of " 1 ", “ 2 " or " 3 ", with 1 being the lowest degree of weathering and 3 being the highest. As categorisation was carried out under the naked eye, pellets were assessed using two evident features of photo-oxidative stress: (1) yellowing and (2) surface cracking [37,60]. Examples of the visual features used to categorise weathering are illustrated in Figure $2 \mathrm{~b}$. A pellet was given a weathering score of " 1 " when neither yellowing nor cracking were present, " 2 " when either yellowing or cracking was present and " 3 " if yellowing and cracking were both present. The sub-samples from each site were then sent to the Institute of Environmental Science and Research (ESR) for polymer characterisation using density separation analysis, whereby a polymer type is assigned relative to a pellet's ability to float (see details of solutions used in Table 1). Following density separation, shavings of a subset of pellets $(n=40)$ were put in a diamond compression cell and analysed for their polymer type with Fourier transform infrared (FTIR) spectroscopy using a Perkin-Elmer Spotlight 200i instrument and attenuated total reflection sampling to check the accuracy of the density separation method. Each pellet was scanned at $4 \times$ and only spectra with $>75 \%$ matches were accepted. If below $75 \%$, a portion of the pellet was shaved and analysed in a diamond compression cell to enhance the clarity of the spectra.

Table 1. Series of solutions used for density separation analysis of pre-production pellets. Pellets that sunk in all solutions were assumed to be polyethylene terephthalate or polyvinyl chloride (both $\left.1.38 \mathrm{~g} / \mathrm{cm}^{3}\right)$.

\begin{tabular}{ccc}
\hline Solution & Polymer & Polymer Density $\left(\mathbf{g} / \mathrm{cm}^{3}\right)$ \\
\hline $100 \%$ Ethanol & Expanded polystyrene & $0.03-0.05$ \\
$58 \%$ Ethanol & Polypropylene & $0.90-0.92$ \\
$43 \%$ Ethanol & LDPE & $0.92-0.93$ \\
Water & HDPE & $0.93-0.97$ \\
Potassium Carbonate & Polystyrene & $0.96-1.04$ \\
\hline
\end{tabular}




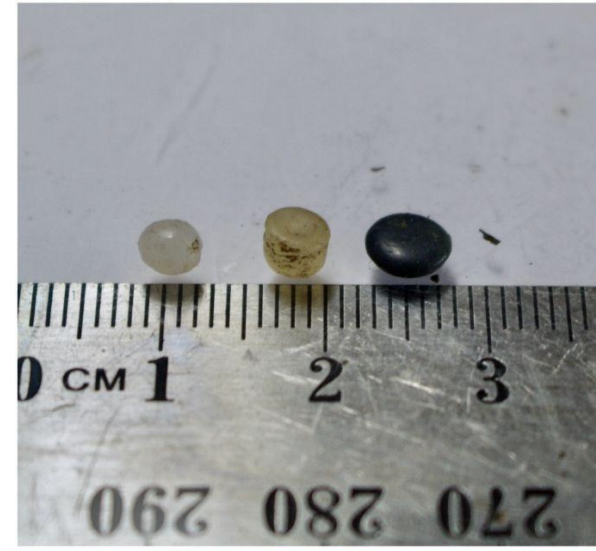

(a)

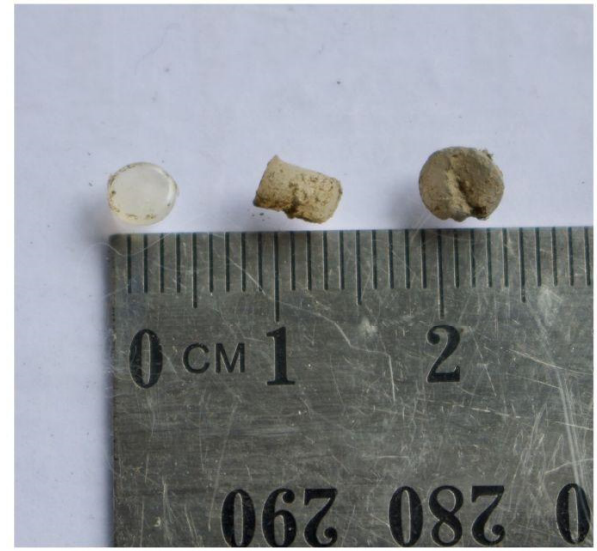

(b)

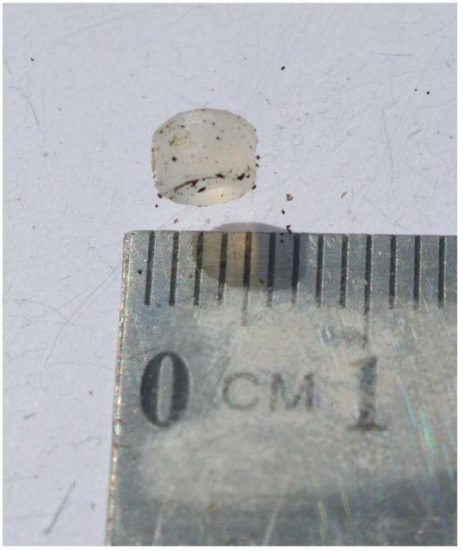

(c)

Figure 2. Pellet classification: (a) by shape, from left to right—spherical, cylindrical, lentil, (b) by weathering, from left to right—category " 1 " no yellowing or cracking, category "2" yellowing only, category " 3 " yellowing and cracking visible; (c) an exemplar pellet classified as $4 \mathrm{~mm}$ size, cylindrical and category " 1 " weathering.

\subsection{Statistical Analysis}

Pellet abundance and density in sediment (pellets $\mathrm{m}^{-3}$ ) data were summarised using the median and interquartile range (IQR), as both datasets took on a skewed distribution. A negative binomial linear model was used to compare the abundance of pellets between geographical locations (based on wind direction) and site (nested within geographical location), to account for overdispersion in the data, with sediment volume included as a weighting variable to account for differences between the samples.

In order to compare colour composition between sites, permutational multivariate analysis of variance (the adonis function in "vegan" package for R) was used. The analysis was undertaken based on Bray-Curtis dissimilarity index values.

In the analysis of the pellet characteristics, a Pearson's chi-square test of independence was performed to examine the relationship between site and the four characteristics measured: pellet size, shape, degree of weathering and polymer type. If over $20 \%$ of the expected counts had values less than 5, a Pearson's chi-squared test with simulated $p$-values (based on $1 \times 10^{6}$ replicates) was carried out instead.

\section{Results}

\subsection{Rapid Estuary Assessment}

The results of the rapid estuary assessment are depicted in Figure 3 and confirmed the presence of pellets around the majority of the Avon-Heathcote Estuary/Ihutai perimeter. A total of 318 pellet hotspots were recorded: 228 hotspots had LOW (5-10 pellets) abundance, 62 had MEDIUM (10-20 pellets) abundance and 28 had HIGH (20+ pellets) abundance. Visual assessment along the "Estuary Green Edge" did not occur, as through access was not granted prior to data collection.

From the data collected in the rapid estuary assessment (Figure 3), the seven sites with the largest clusters of pellet hotspots and thus selected for sampling were Ferrymead Bridge, Humphreys Drive, Sandy Point, Bridge Street, South New Brighton Park, Penguin Street and Southshore Spit. For analysis, the seven sites were grouped according to their geographical location in relation to wind direction. Ferrymead Bridge, Humphreys Drive and Sandy Point were categorised as being in the southwest of the estuary, Bridge Street and South New Brighton Park in the east and Penguin Street and Southshore Spit in the southeast (Figure 4). 


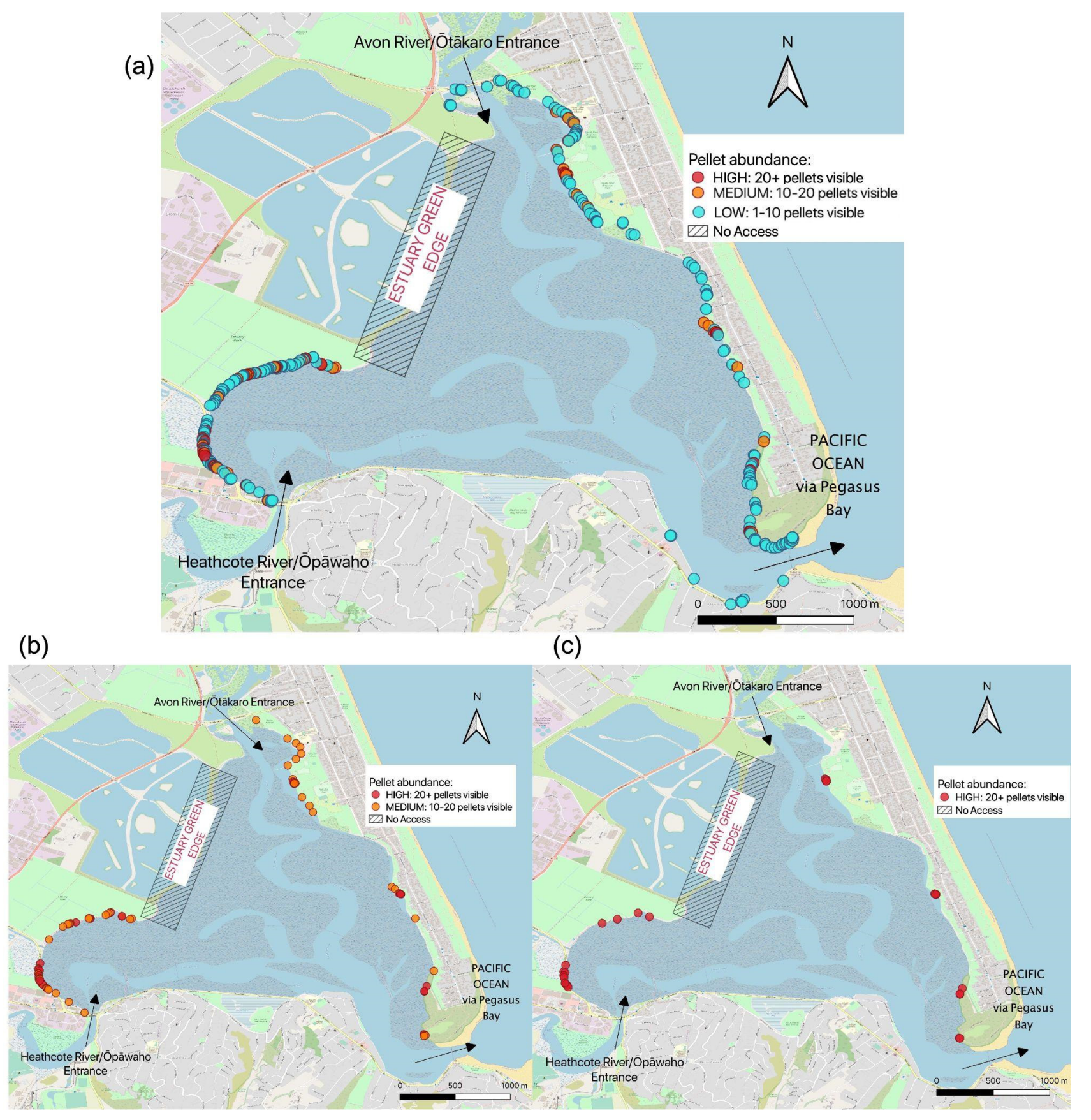

Figure 3. Visualisation of the rapid estuary assessment: locations of hotspots at: (a) all levels of pellet abundance $(n=318)$; (b) high and medium pellet abundance only $(n=90)$, and; (c) high pellet abundance only $(n=28)$. 


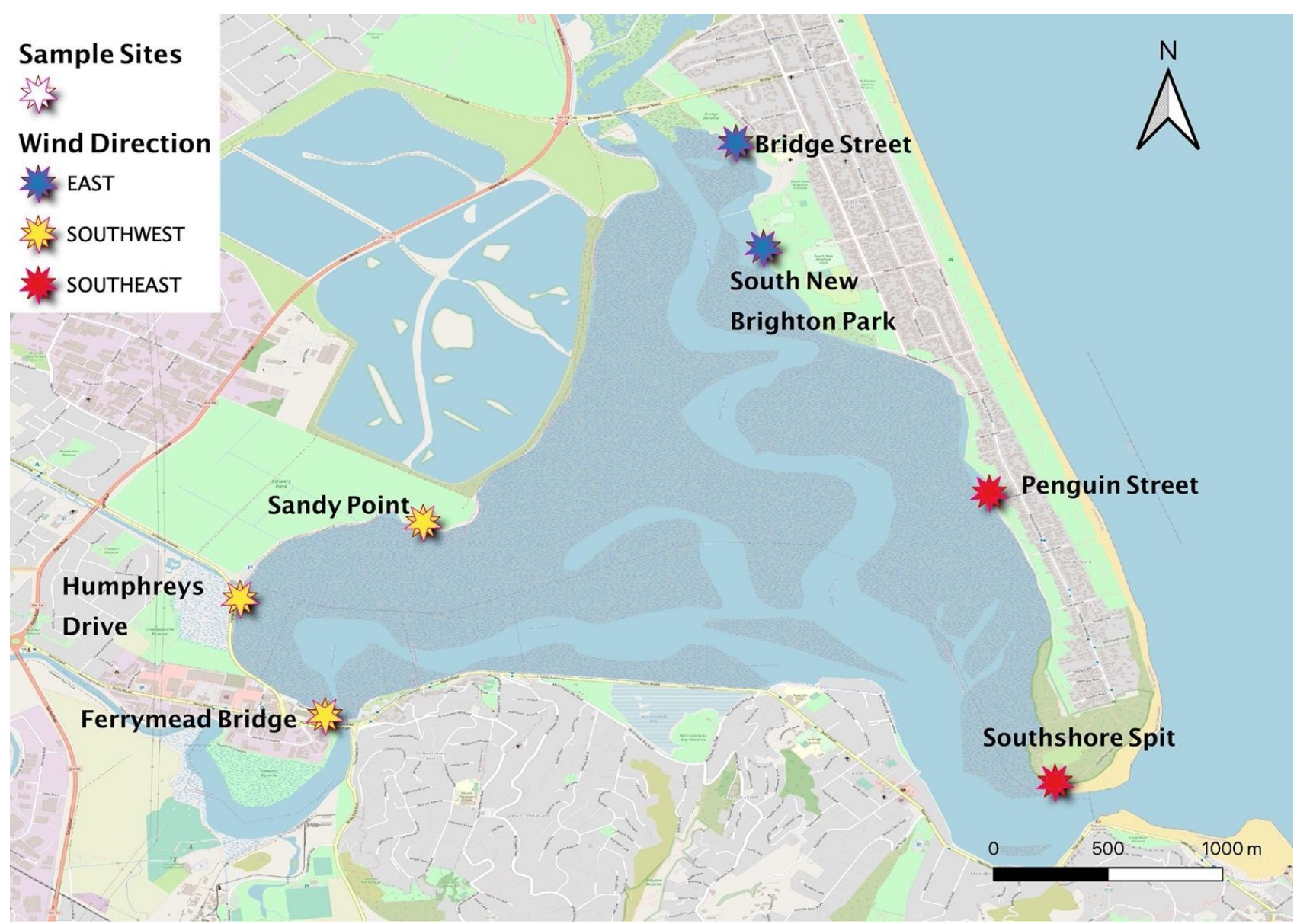

Figure 4. The seven sites selected for sampling using the information obtained during the rapid estuary assessment. The seven sites, indicated by star symbols, were categorised by three wind directions common to the area that may influence pellet deposition.

\subsection{Pellet Abundance and Density}

Pellets were identified at all sites $(n=7)$ and $94 \%$ of samples $(n=33)$ had pellets extracted from them. The total number of pellets observed was 3819 (Table 2). The abundance of pellets per sample ranged from 0 (Ferrymead Bridge/Bridge Street/Sandy Point) to 852 pellets (Sandy Point). The total pellet abundance per site ranged from 81 (Southshore Spit) to 1538 (Humphreys Drive) pellets (Table 2, Figure 5). Averaging across the samples taken at all sites, the median pellet density was estimated at 7680 pellets $\mathrm{m}^{-3}$ of sediment (IQR: $3200-39,840$ pellets $\mathrm{m}^{-3}$ ) and median pellet abundance was estimated at 24 pellets (IQR: $10-93$ pellets).

The analysis of pellet abundance indicated that there was a significant difference in abundance between all geographical locations $\left(\chi^{2}=5299, \mathrm{df}=2,32, p<0.0001\right)$, with the highest mean values in the southwest, followed by the east and southeast. There were also significant differences in pellet counts between all sites within locations $\left(\chi^{2}=2045, \mathrm{df}=4\right.$, $32, p<0.0001)$, indicating significant variability at a site level within locations, as shown in Figure 5 (which shows density rather than count to present information corrected for sediment volume). 
Table 2. Abundance of pre-production pellets found in the Avon-Heathcote Estuary/Ihutai, categorised by colour and site.

\begin{tabular}{|c|c|c|c|c|c|c|c|c|}
\hline & Clear & White & Black & Red & Blue & Yellow & Green & Total per Site \\
\hline Ferrymead Bridge & 227 & 15 & 45 & 0 & 4 & 0 & 1 & 292 \\
\hline Humphreys Drive & 1311 & 79 & 124 & 0 & 19 & 3 & 2 & 1538 \\
\hline Sandy Point & 1081 & 15 & 105 & 2 & 21 & 2 & 1 & 1227 \\
\hline Bridge Street & 401 & 21 & 17 & 0 & 6 & 0 & 1 & 446 \\
\hline South New Brighton Park & 119 & 2 & 15 & 0 & 1 & 0 & 0 & 137 \\
\hline Penguin Street & 87 & 2 & 8 & 0 & 1 & 0 & 0 & 98 \\
\hline Southshore Spit & 73 & 1 & 7 & 0 & 0 & 0 & 0 & 81 \\
\hline TOTAL per colour & 3299 & 135 & 321 & 2 & 52 & 5 & 5 & 3819 \\
\hline
\end{tabular}

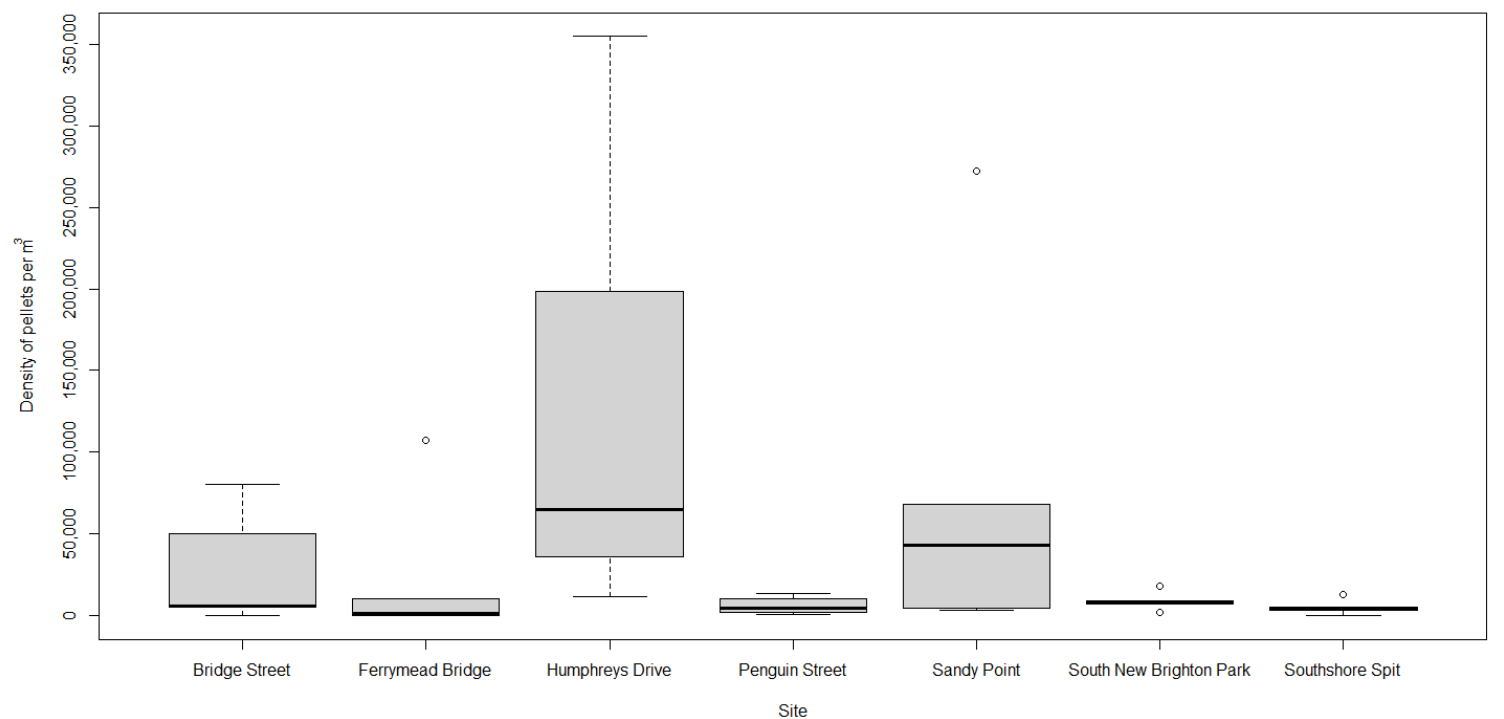

Figure 5. Box-and-whisker plots displaying the average and variation of pellet density (pellets $\mathrm{m}^{-3}$ ) per site. The interquartile range is represented by the length of each box and the median values are represented by the thick line in the middle of the box. Minimum and maximum values are at the end of each whisker. Outliers are visualised as open circles.

In addition, at Humphreys Drive, hard substrate within most sampling quadrats could not be extracted and density values had to be adjusted to reflect this. The variability of this site justified its removal from the model. The pellet abundance at Bridge Street was significantly higher than the Ferrymead Bridge, Southshore Spit and Penguin Street sites $\left(\chi^{2}=25.59, \mathrm{df}=5.23, p<0.001\right)$. The mean pellet count at Ferrymead Bridge was $90 \%$ lower (SE Range $=76-95 \%, p=0.006$ ), Southshore Spit was 82\% lower (SE Range $=61-92 \%$, $p=0.027$ ) and Penguin Street was 78\% lower (SE Range $=52-90 \%, p=0.050$ ) than the mean of 89 pellets observed at Bridge Street (SE Range $=52-15)$. In addition, the geographical location associated with downwind direction (Figure 4) was significantly related to pellet count $\left(\chi^{2}=15.8, \mathrm{df}=2.32, p<0.001\right)$. The mean pellet count for sites in the east was 58 pellets (SE Range $=38-90)$ (Figure 5). The mean pellet count at southwest sites was 3.50 times larger (SE Range $=2.00-6.18, p=0.026$ ) than that found in the east.

\subsection{Pellet Colour Composition}

Across the samples $(n=35)$, the colours of pellets identified were clear, white, black, red, blue, yellow and green. Clear pellets were the most abundant, followed by black, white and blue (Table 2). The permutational multivariate analysis of variance showed there was 
no significant difference in colour abundance between sites $\left(R^{2}=0.23, \mathrm{df}=6.25, p=0.262\right)$, with the average similarity of composition being $67 \%$.

\subsection{Pellet Size}

The most common pellet size class overall was " $3 \mathrm{~mm}$ " (54\%). This size class of pellet was found in the highest proportion at all sites. At every site, over $50 \%$ of the pellets categorised were in the " $3 \mathrm{~mm}$ " size class, ranging from $51 \%$ (Bridge Street) to $70 \%$ (Southshore Spit). There were significant differences between sites in terms of frequency of size classes $\left(x^{2}=63.60, p=0.01\right.$, Figure $\left.6 a\right)$. Penguin Street was the only site to record pellets in the size class " $1 \mathrm{~mm}$ " $(4 \%)$ and Southshore Spit was the only site where pellets in the size class " $5 \mathrm{~mm}$ " were not observed. South New Brighton Park had the highest percentage of " $2 \mathrm{~mm}^{\prime}$ " pellets observed (21\%) and Southshore Spit had the lowest (5\%). Sandy Point had the highest percentage of pellets of the size class " $4 \mathrm{~mm}^{\text {" }}(33 \%)$ and South New Brighton Park had the lowest (18\%).

(a) Pellet Size

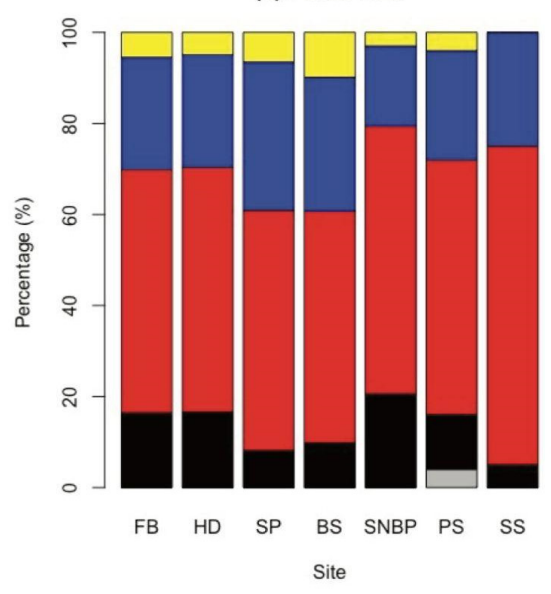

(c) Pellet Weathering

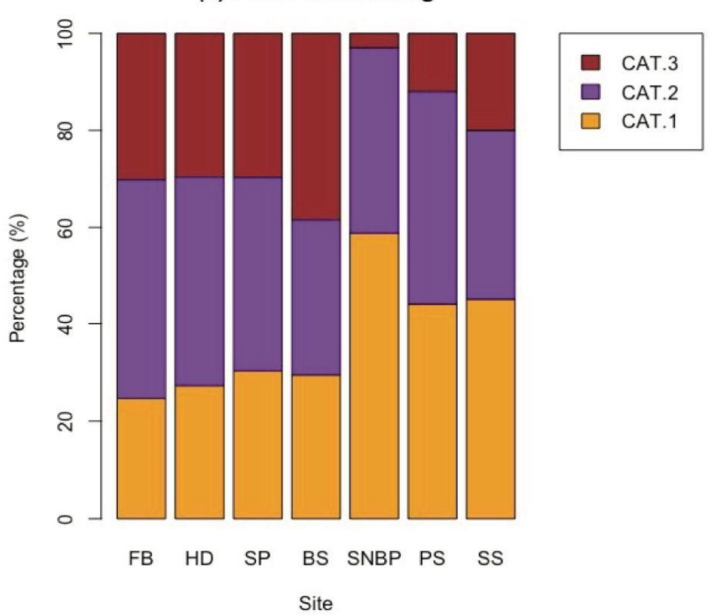

(b) Pellet Shape

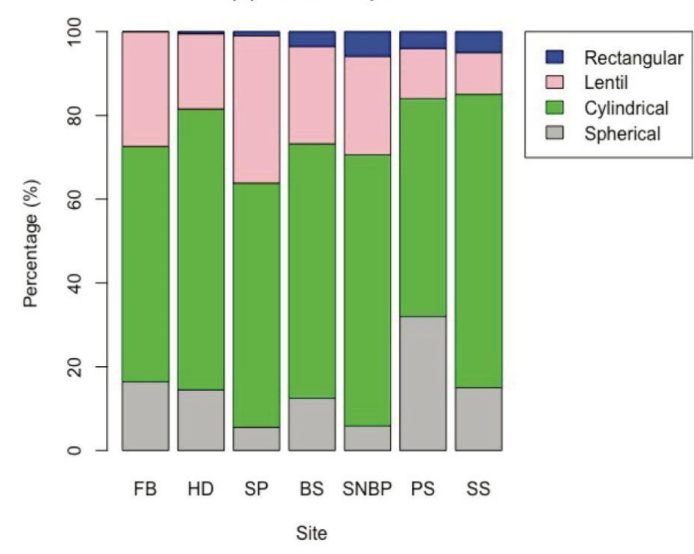

(d) Pellet Polymer Type

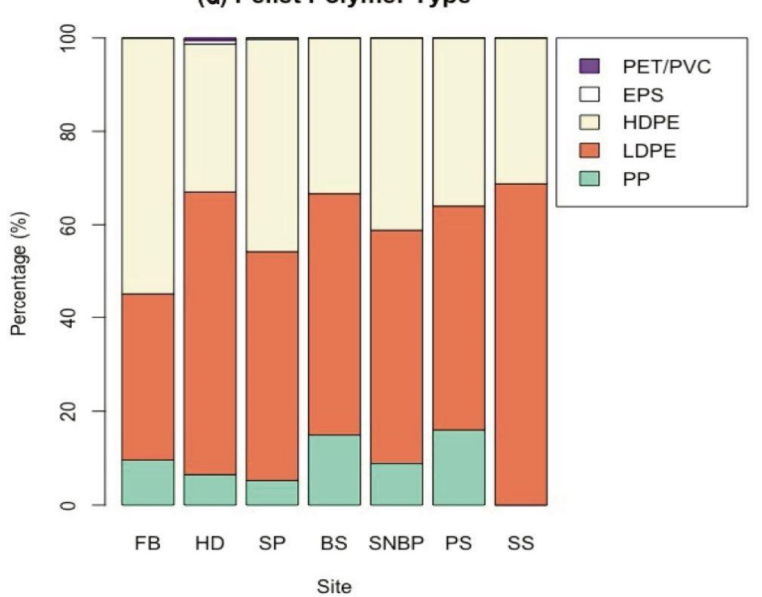

Figure 6. Percentage of pellet characteristics observed in the sub-sample of each site. FB $=$ Ferrymead Bridge $(n=73)$, HD = Humphreys Drive $(n=385)$, SP $=$ Sandy Point $(n=307)$, BS $=$ Bridge Street $(n=112)$, SNBP = South New Brighton Park $(n=34)$, PS = Penguin Street $(n=25)$, SS = Southshore Spit $(n=20)$ : (a) Pellet Size-“1 mm", "2 mm”, “3 mm", " 4 mm", "5 mm"; (b) Pellet Shape-“Rectangular", "Lentil", "Cylindrical", "Spherical”; (c) Pellet Weathering categories-“1", "2", "3"; and (d) Pellet Polymer types- "PET/PVC"= polyethylene terephthalate and polyvinyl chloride, "EPS" = expanded polystyrene, "HDPE" = high density polyethylene, "LDPE" = low density polyethylene, and "PP"= polypropylene. 


\subsection{Pellet Shape}

The most common pellet shape overall was cylindrical (62\%). Cylindrical pellets were also present in the highest proportion at all sites. The percentage of cylindrical shaped pellets recorded at a site ranged from 56\% (Ferrymead Bridge) to 70\% (Southshore Spit) (Figure $6 \mathrm{~b}$ ). There was a significant difference between sites in the frequency of pellet shapes observed $\left(\chi^{2}=67.56, p<0.001\right.$, Figure $\left.6 b\right)$. Rectangular shaped pellets were the least observed at all sites and percentages present at each site ranged from $0 \%$ (Ferrymead Bridge) to $6 \%$ (South New Brighton Park). In addition, there was considerable variance between sites in the proportion of lentil and spherical shaped pellets recorded. Lentil shaped pellets range from 10\% (Southshore Spit) to 35\% (Sandy Point) and spherical pellets from 6\% (Sandy Point and South New Brighton Park) to 32\% (Penguin Street) of the total number of pellets categorised.

\subsection{Pellet Weathering}

Overall, the pellets were most frequently identified to possess either yellowing or cracking and were recorded as category " 2 " weathering $(41 \%)$. Across all sites, the pellets in weathering category " 2 " were most abundant $(n=389)$, followed by those with no sign of weathering in category " 1 " $(n=289)$ and those with both yellowing and cracking in category " 3 " ( $n=278)$. Per site, the estimated median number of pellets categorised as " 2 " was 33 pellets (IQR: $12-80$ pellets), for " 1 " was 20 pellets (IQR:15-63 pellets) and for " 3 " was 22 pellets (IQR: 4-67 pellets). There were significant differences in the frequency of different degrees of weathering between sites $\left(x^{2}=31.84, p=0.001\right.$, Figure $\left.6 c\right)$. Pellets with a category " 2 " of weathering were most abundant at Ferrymead Bridge (45\%), Humphreys Drive (43\%) and Sandy Point (40\%). At Penguin Street, pellets in categories "1" and "2" were jointly most abundant (44\%). At Bridge Street, category "3" pellets made up the highest proportion of pellets recorded (38\%). At South New Brighton Park and Southshore Spit, category " 1 " pellets made up the highest proportion of pellets recorded ( $59 \%$ and $45 \%$, respectively).

\subsection{Pellet Polymer Type}

Low density polyethylene (LDPE) was the predominant (53.1\%) polymer type identified, with high density polyethylene (HDPE) the second most common (38.8\%) (Figure 6d). Polypropylene (PP) $(7.5 \%)$, expanded polystyrene (EPS) $(0.4 \%)$ and polyethylene terephthalate (PET) and polyvinyl chloride (PVC) $(0.2 \%)$ were also seen. PET and PVC were combined into a single category, as the similarity of their densities did not allow them to be distinguished. There were significant differences in the frequency of polymer types between sites $\left(\chi^{2}=46.25, p=0.04\right.$, Figure $\left.6 \mathrm{~d}\right)$. The most abundant polymer type at every site was LDPE, with the exception of Ferrymead Bridge, where it was HDPE (55\%, Figure $6 \mathrm{~d}$ ). Southshore Spit was the only site where pellets made of polypropylene were not identified. Humphreys Drive was the only site where EPS and PET were identified. Out of the 40 pellets put through the FTIR analysis using the diamond compression cell, 33 matched the results of the density separation analysis. Three more HDPE pellets, two less LDPE pellets and one less PP were identified compared to the results of floatation.

\section{Discussion}

It is evident that, as has been reported in other estuarine ecosystems [47], pre-production pellets are widely distributed and abundant within the Avon-Heathcote Estuary/Ihutai. A total of 3819 pellets were identified across 7 sites and 35 samples, with a median pellet density of 7680 pellets $\mathrm{m}^{-3}$ of sediment (IQR: $3200-39840$ pellets $\mathrm{m}^{-3}$ ). The high concentrations of pellets and the presence of multiple plastic manufacturers within the immediate catchment support the assertion that pellets are being lost from the plastics industry to the environment and accumulating in the estuary. It is acknowledged that pellet density estimates in this study may be overestimated, as only the top $5 \mathrm{~cm}$ of sediment was sampled. Heterogeneity of pellet distribution, particularly in sediment deeper than $5 \mathrm{~cm}$, is likely to 
occur [55]. It raises the need to establish a standard when reporting the results of sediment sampling. A depth threshold should be established at which the abundance of microplastics should be reported in terms of density $\left(\mathrm{m}^{-3}\right)$ instead of area $\left(\mathrm{m}^{2}\right)$. International studies that evaluated microplastic contamination per area of sediment have also reported notable densities of microplastics like in the Avon-Heathcote Estuary/Ihutai. On the beaches of Hong Kong, a median of 298 items per $\mathrm{m}^{2}$ of sediment was identified [61] and an average of 27 microplastic items per $\mathrm{m}^{2}$ were found on the continental coast of Chile and Easter Island [62]. Specifically addressing pellet contamination, comparably high levels were found upon water surface sampling of the River Rhine (8848 particles $1000 \mathrm{~m}^{-3}$ at Duisburg and 11,050 particles $1000 \mathrm{~m}^{-3}$ at Rees) [31]. The explanation given for this was the presence of plastic manufacturers along the length of the Rhine, which is also applicable for the Ōpāwaho/Heathcote River (Figure 1). The present study focused solely on the presence of pellets, but their abundance suggests pollution from other types of microplastics is likely via similar mechanisms. In addition to pellets, pre-production plastic comes in flake and powder forms that can also be lost from industry [33]. Moreover, other freshwater environments have found a dominance of microplastic fibre contamination [63-65] and these may pose a greater risk of ingestion by aquatic organisms [18]. Based on this, the overall microplastic contamination in the estuary is likely to be much higher than the values reported for pellets alone.

Although pellets were widely distributed across the estuary, there were a number of hotspots where accumulation was particularly high. There are several factors that could have influenced this pattern of accumulation. When the seven hotspots were divided into three groups depending on their downwind location (southwest, east and southeast), the southwest sites had significantly higher pellet abundance than the east or southeast sites. The prevailing wind direction for the estuary area in September and October 2020 was north-easterly which could explain the high abundance of pellets in downwind southwest locations given that the sampling took place in early October. The downwind accumulation of plastic debris is well documented in several studies, such as on the eastern coast of Goa, India, following a southwest monsoon [60] and in the Tamar Estuary, UK [66]. Repeating the study in a period of predominantly westerly/south-westerly winds with the hypothesis that pellet abundance would be greater at easterly locations would confirm the influence of wind in pellet distribution. Given that predominant wind patterns change throughout the year in the Canterbury region [67], seasonality is also a confounding factor on microplastic accumulation in the estuary, as found by other studies [61,68].

Both rivers that drain into the estuary are likely to be significant conduits of pellets, which will receive them via stormwater outlets and drains from industry $[67,69]$ and pellet spills during transport or handling [33] occurring upstream. Field measurements of run-off from these drains, or, better yet, the manufacturers themselves, could shed light on specific sources [70].

Comparing the hotspots adjacent to the river mouths showed that there was higher pellet abundance at Bridge Street $(n=446)$ than Ferrymead Bridge $(n=292)$. This could suggest that the Ôtākaro/Avon is transporting more pellets into the estuary than the Ōpāwaho/Heathcote River, which may, in turn, relate to the higher mean annual flow rate $\left(3.2 \mathrm{~m}^{3} / \mathrm{s}\right.$ vs. $\left.1.0 \mathrm{~m}^{3} / \mathrm{s}[71]\right)$. However, the pattern of abundance within the estuary would suggest that there is significant redistribution by water circulation patterns driven by wind and potentially also tidal action [66].

Within sites, there was a high degree of variation in the pellet abundance between samples. This sample heterogeneity aligns with previous studies in A-NZ [45], Belgium [70] and Italy [72], emphasising spatial variability as a challenge when it comes to microplastic quantification. Heterogeneity between samples could be accounted for by different substrate types; for example, pellets have been shown to accumulate in higher abundance on sandy shorelines compared to adjacent rocky areas [73]. Details of the substrate type of each sample can be found in Table S1. For example, Humphreys Drive was the only site where the complete volume of sediment could not be extracted from the sampling quadrat 
due to pellet accumulation occurring on a concrete flood wall and this site demonstrated high variability, with samples containing between 28 and 777 pellets. To gain a better understanding of the accumulation of pellets at these sites, more detailed sampling may be required to characterise the patterns of spatial variation. Likewise, substrate type could account for the lack of pellets observed during the rapid estuary assessment along the southern border of the estuary. There are rip-rap walls in this location that prevented the assessment for pellets in this area.

The inability to sample along the "Estuary Green Edge" is also a limitation to the full assessment of the situation. This is adjacent to the municipal wastewater treatment plant (Figure 3). Microplastics concentrations have been shown to positively correlate with the proximity to sewage outfalls [66]. Historically, this area of the estuary was subject to approximately 30 million gallons of effluent discharge per day [74] until 2010, when the discharge was directed to an ocean outfall. Due to the persistent nature of plastic, any discharged pellets prior to 2010 could still be retained in the system and be mobilised by extreme weather events.

The most frequently identified characteristics of the pellets in the Avon-Heathcote Estuary/Ihutai were clear, cylindrical, $3 \mathrm{~mm}$ size, made of LDPE and with a category "2" of weathering. This aligns with the findings of Clunies-Ross et al. [45], where microplastics between $2-5 \mathrm{~mm}$ and white or clear were most common, although the abundance of pellets less than $2 \mathrm{~mm}$ may have been underestimated in this study. The wide distribution of cylindrical pellets can be explained by the smooth sides allowing for further travel than sharper edged pellets [56]. Clear pellet prevalence could be attributed to the high demand for clear polymers for use in packaging production [4] and clear pellets give plastic manufacturers the ability to add their desired colours at the remanufacturing stage [33]. Pellet colour can also influence a pellet's potential to be mistaken for prey by wildlife. For example, white/opaque pellets have been shown to be selectively consumed by some fish [75]. This may be occurring when pellets are mobilised in the water column.

Category " 2 " weathering, whereby pellets displayed either yellowing or cracking, was most prevalent, suggesting some amount of pellet retention in the estuary. The dominant polymer type was PE, which is vulnerable to degradation [76]. Given that pellet accumulation occurred above the strandline where pellets would be subject to high UV radiation, temperatures and hydrolysis, it is not surprising that most pellets were partly weathered. Of note is the high abundance of pellets with category "1" or no weathering in South New Brighton Park (59\%). This could be explained by recent entry to the environment, close proximity of the point source to the sample area or the resurfacing of pellets that had been buried and previously protected from weathering. In contrast, over a third of the pellets categorised from Bridge Street had a category " 3 ", high level of weathering, suggesting a long period of retention. This could explain the high abundance of pellets at this site in comparison to Ferrymead Bridge, Penguin Street and Southshore Spit, despite not being situated in a downwind location. Pellets could have accumulated in that area during a period of westerly/south-westerly winds and have become lodged due to local topography [77]. The presence of category " 3 " weathered pellets raises further concern for local wildlife, as several studies have found a correlation between the discolouration/brittleness of a pellet and the concentration of organic pollutants it has absorbed $[19,78]$. Sandy Point has been recorded to have the highest concentration of metals across estuary sites and both Southshore Spit and Sandy Point have presented with copper concentrations above the recommended guidelines [79]. Metals such as copper have been documented to be absorbed by plastic $[20,80]$ and pellets made from LDPE and HDPE, which are most prevalent in the estuary, have shown a higher potential to absorb hazardous chemicals than other plastics such as PVC and PET [81]. This also suggests that the pellets may present a direct chemical hazard to biota due to the associated chemicals.

The large spatial range of LDPE and HDPE pellets may be related to their low density (specific gravity of PE: $0.91-0.97$ vs. 1.025 for seawater), which allows for floatation [26] and therefore dispersion from the source of pollution. The low abundance of PP in this 
study cannot be attributed to a lack of dispersion, as they are more buoyant and travel further than PE pellets [56]. The low abundance of denser plastics such as PVC and PET could be explained by localised sinking close to the pollution source. Wind has been shown to be more influential on the dispersion of higher density plastics [66], which could account for the presence of PVC and PET at Humphreys Drive, a downwind location. It is acknowledged that the low representation of higher density plastics could have been skewed by the reduction of sample material via floatation in the field. Pellets that have been heavily bio-fouled or are of higher density will sink [33,82] and may not have been collected in the sample. However, negatively buoyant polymers have been collected while using surface sampling methods [65], suggesting that the dynamic nature of the estuary and the sediment separation procedure would impede pellet settlement, reducing pellet loss at this stage. Additional factors that can alter a pellet's buoyancy include the addition of additives during manufacture $[2,26]$ and the introduction of air bubbles during moulding [83]. It is clear that the location of pellet accumulation does not directly correlate with the contamination source.

Identifying the dominant characteristics of the pellets (polymer, colour, size, etc.) may help in efforts to reduce releases. Polymer type can be linked to product type: the largest market for polyethylene is film [2] and packaging [6], with LDPE used in heavy duty items such as protective sheeting, industrial pipes and long-life carrier bags, whereas HDPE is used in thinner gauged carrier bags and food wraps [84]. This, in turn, can help to localise likely sources and hence engagement with manufacturers to improve management. A number of the local plastic manufacturers have adopted Operation Clean Sweep's (OCS) best management practices for zero pellet loss [43]. The high number of pellets $(n=3819)$ recorded in this study suggests that further work is still required. An evaluation could be made between the management practices of those companies who have adopted OCS's best management practices and are part of Plastics NZ, versus those who are not associated (Figure 1) and highlight measures that are proving effective and those that are not. Preventative measures such as the installation of effective filters in drain pipes to capture pellets before release [69] are readily available and should be implemented. The co-operation of the plastics industry in the prevention of release is a key component in combating plastic pollution [41].

\section{Conclusions}

The present study confirms the presence of pre-production pellets in the AvonHeathcote Estuary/Ihutai at relatively high concentrations in comparison to international studies on microplastics $[31,61,62]$ and given that pre-production pellets are only one type of microplastic, the overall concentration of microplastics is likely to be even higher. This presents a hazard to local wildlife and overall ecosystem health. The most common characteristics of the pellets found were clear in colour, cylindrical, $3 \mathrm{~mm}$ in the widest dimension, partly weathered and made from polyethylene, which correlates to the high usage of this polymer and also the manufacturers in the catchment. The widespread distribution of pellets in the estuary suggests there are many factors involved in where they accumulate. Pellet characteristics will influence their dispersal, along with factors such as wind, seasonality and tidal flows. Entry points are likely to be the Ōtākaro/Avon River and the Ōpāwaho/Heathcote River in addition to stormwater and drain outlets. These factors make highlighting a specific point source difficult, but the local plastics industry in Otautahi/Christchurch has a responsibility to address pellet loss sooner rather than later in order to protect this important ecosystem.

Supplementary Materials: The following supporting information can be downloaded at: https: / / www.mdpi.com/article/10.3390/microplastics1010005/s1, Table S1: Visuals of sampling sites and sample quadrats with details of substrate types.

Author Contributions: E.C.H.: conceptualization, methodology, formal analysis, writing—original draft, writing — review and editing, visualisation, project administration. R.d.V.: conceptualisation, 
methodology, resources, writing - review and editing. P.C.-R.: conceptualisation, methodology, writing-review and editing. O.P.: resources, methodology, writing-review and editing. F.D. and H.M.: methodology. H.M.: methodology. R.A.B.: conceptualisation, methodology, formal analysis, writing - review and editing, supervision. All authors have read and agreed to the published version of the manuscript.

Funding: This research received no external funding.

Institutional Review Board Statement: Not applicable.

Informed Consent Statement: Not applicable.

Data Availability Statement: Data available in a publicly accessible repository. The data presented in this study are openly available in GitHub: https: / / doi.org/10.5281/zenodo.5850489 (accessed on 1 December 2021).

Acknowledgments: The authors are grateful for the assistance and support of Lesley Bolton-Richie (Environment Canterbury) and the Avon-Heathcote Estuary/Ihutai Trust.

Conflicts of Interest: The authors declare no conflict of interest. The Institute of Environmental Science and Research Ltd undertook polymer characterization analysis of the microplastic pellet samples.

\section{References}

1. Thompson, R.C.; Swan, S.H.; Moore, C.J.; vom Saal, F.S. Our Plastic Age. Philos. Trans. R. Soc. B 2009, 364, 1973-1976. [CrossRef]

2. Andrady, A.L.; Neal, M.A. Applications and Societal Benefits of Plastics. Philos. Trans. R. Soc. B 2009, 364, 1977-1984. [CrossRef]

3. Laist, D.W. Overview of the Biological Effects of Lost and Discarded Plastic Debris in the Marine Environment. Mar. Pollut. Bull. 1987, 18, 319-326. [CrossRef]

4. Plastics Europe. Plastics-The Facts 2020. An Analysis of European Plastics Production, Demand and Waste Data; Plastics Europe, Association of Plastic Manufacturers: Brussels, Belgium, 2019. Available online: https://plasticseurope.org/wp-content/ uploads / 2021/10/2019-Plastics-the-facts.pdf (accessed on 27 November 2021).

5. $\quad$ Eriksen, M.; Lebreton, L.C.M.; Carson, H.S.; Thiel, M.; Moore, C.J.; Borerro, J.C.; Galgani, F.; Ryan, P.G.; Reisser, J. Plastic Pollution in the World's Oceans: More than 5 Trillion Plastic Pieces Weighing over 250,000 Tons Afloat at Sea. PLoS ONE 2014, 9 , e111913. [CrossRef]

6. Geyer, R.; Jambeck, J.R.; Law, K.L. Production, Use, and Fate of All Plastics Ever Made. Sci. Adv. 2017, 3, e1700782. [CrossRef] [PubMed]

7. Barnes, D.K.A.; Galgani, F.; Thompson, R.C.; Barlaz, M. Accumulation and Fragmentation of Plastic Debris in Global Environments. Philos. Trans. R. Soc. B 2009, 364, 1985-1998. [CrossRef]

8. United Nations Environment Programme (UNEP). 1989 Basel Convention on the Control of Transboundary Movements in Hazardous Wastes and Their Disposal. Adopted 22 March 1989, 28 ILM 657 (in force 2 May 1992), Geneva, CH. Available online: http:/ / www.basel.int (accessed on 27 November 2021).

9. Nel, H.A.; Dalu, T.; Wasserman, R.J. Sinks and Sources: Assessing Microplastic Abundance in River Sediment and Deposit Feeders in an Austral Temperate Urban River System. Sci. Total Environ. 2018, 612, 950-956. [CrossRef] [PubMed]

10. Mascarenhas, R.; Santos, R.; Zeppelini, D. Plastic Debris Ingestion by Sea Turtle in Paraíba, Brazil. Mar. Pollut. Bull. 2004, 49, 354-355. [CrossRef]

11. Bugoni, L.; Krause, L.; Petry, M.V. Marine Debris and Human Impacts on Sea Turtles in Southern Brazil. Mar. Pollut. Bull. 2001, 42, 1330-1334. [CrossRef]

12. Tomás, J.; Guitart, R.; Mateo, R.; Raga, J.A. Marine Debris Ingestion in Loggerhead Sea Turtles, Caretta Caretta, from the Western Mediterranean. Mar. Pollut. Bull. 2002, 44, 211-216. [CrossRef]

13. Robards, M.D.; Piatt, J.F.; Wohl, K.D. Increasing Frequency of Plastic Particles Ingested by Seabirds in the Subarctic North Pacific. Mar. Pollut. Bull. 1995, 30, 151-157. [CrossRef]

14. Blight, L.K.; Burger, A.E. Occurrence of Plastic Particles in Seabirds from the Eastern North Pacific. Mar. Pollut. Bull. 1997, 34, 323-325. [CrossRef]

15. Van Franeker, J.A.; Heubeck, M.; Fairclough, K.; Turner, D.M.; Grantham, M.; Stienen, E.W.M.; Guse, N.; Pedersen, J.; Olsen, K.O.; Andersson, P.J. 'Save the North Sea' Fulmar Study 2002-2004: A Regional Pilot Project for the Fulmar-Litter-EcoQO in the OSPAR Area; Alterra: Wageningen, The Netherlands, 2005.

16. Nelms, S.E.; Galloway, T.S.; Godley, B.J.; Jarvis, D.S.; Lindeque, P.K. Investigating Microplastic Trophic Transfer in Marine Top Predators. Environ. Pollut. 2018, 238, 999-1007. [CrossRef]

17. Moore, C.J. Synthetic Polymers in the Marine Environment: A Rapidly Increasing, Long-Term Threat. Environ. Res. 2008, 108, 131-139. [CrossRef] [PubMed]

18. Wright, S.L.; Thompson, R.C.; Galloway, T.S. The Physical Impacts of Microplastics on Marine Organisms: A Review. Environ. Pollut. 2013, 178, 483-492. [CrossRef] [PubMed] 
19. Mato, Y.; Isobe, T.; Takada, H.; Kanehiro, H.; Ohtake, C.; Kaminuma, T. Plastic Resin Pellets as a Transport Medium for Toxic Chemicals in the Marine Environment. Environ. Sci. Technol. 2001, 35, 318-324. [CrossRef]

20. Brennecke, D.; Duarte, B.; Paiva, F.; Caçador, I.; Canning-Clode, J. Microplastics as Vector for Heavy Metal Contamination from the Marine Environment. Estuar. Coast. Shelf Sci. 2016, 178, 189-195. [CrossRef]

21. Ryan, P.G.; Bouwman, H.; Moloney, C.L.; Yuyama, M.; Takada, H. Long-Term Decreases in Persistent Organic Pollutants in South African Coastal Waters Detected from Beached Polyethylene Pellets. Mar. Pollut. Bull. 2012, 64, 2756-2760. [CrossRef] [PubMed]

22. Barnes, D.; Fraser, K. Rafting by Five Phyla on Man-Made Flotsam in the Southern Ocean. Mar. Ecol. Prog. Ser. 2003, 262, $289-291$. [CrossRef]

23. Rech, S.; Salmina, S.; Borrell Pichs, Y.J.; García-Vazquez, E. Dispersal of Alien Invasive Species on Anthropogenic Litter from European Mariculture Areas. Mar. Pollut. Bull. 2018, 131, 10-16. [CrossRef] [PubMed]

24. Thompson, R.C.; Olsen, Y.; Mitchell, R.P.; Davis, A.; Rowland, S.J.; John, A.W.G.; McGonigle, D.; Russell, A.E. Lost at Sea: Where Is All the Plastic? Science 2004, 304, 838. [CrossRef]

25. Kershaw, P.J.; Turra, A.; Galgani, F. Guidelines for the Monitoring and Assessment of Plastic Litter and Microplastics in the Ocean; GESAMP Joint Group of Experts on the Scientific Aspects of Marine Environmental Protection: London, UK, 2019. [CrossRef]

26. Andrady, A.L. Microplastics in the Marine Environment. Mar. Pollut. Bull. 2011, 62, 1596-1605. [CrossRef]

27. Eriksen, M.; Mason, S.; Wilson, S.; Box, C.; Zellers, A.; Edwards, W.; Farley, H.; Amato, S. Microplastic Pollution in the Surface Waters of the Laurentian Great Lakes. Mar. Pollut. Bull. 2013, 77, 177-182. [CrossRef] [PubMed]

28. Bowmer, T.; Kershaw, P. GESAMP, UNESCO-IOC. In Proceedings of the GESAMP International Workshop on Microplastic Particles as a Vector in Transporting Persistent, Bio-Accumulating and Toxic Substances in the Ocean, Paris, France, 28-30 June 2010.

29. Browne, M.A.; Crump, P.; Niven, S.J.; Teuten, E.; Tonkin, A.; Galloway, T.; Thompson, R. Accumulation of Microplastic on Shorelines Woldwide: Sources and Sinks. Environ. Sci. Technol. 2011, 45, 9175-9179. [CrossRef]

30. Hurley, R.; Woodward, J.; Rothwell, J.J. Microplastic Contamination of River Beds Significantly Reduced by Catchment-Wide Flooding. Nat. Geosci. 2018, 11, 251-257. [CrossRef]

31. Mani, T.; Hauk, A.; Walter, U.; Burkhardt-Holm, P. Microplastics Profile along the Rhine River. Sci. Rep. 2016, 5, 17988. [CrossRef]

32. Hann, S.; Sherrington, C.; Jamieson, O.; Hickman, M.; Kershaw, P.; Bapasola, A.; Cole, G. Investigating Options for Reducing Releases in the Aquatic Environment of Microplastics Emitted by (but Not Intentionally Added in) Products. Rep. DG Environ. Eur. Comm. 2018, 335.

33. OSPAR Comission. OSPAR Background Document on Pre-Production Plastic Pellets. 2018. Available online: https://www.ospar. org (accessed on 27 November 2021).

34. Derraik, J.G.B. The Pollution of the Marine Environment by Plastic Debris: A Review. Mar. Pollut. Bull. 2002, 44, 842-852. [CrossRef]

35. Zbyszewski, M.; Corcoran, P.L. Distribution and Degradation of Fresh Water Plastic Particles Along the Beaches of Lake Huron, Canada. Water Air Soil Pollut. 2011, 220, 365-372. [CrossRef]

36. Werner, S.; Budziak, A.; van Franeker, J.; Galgani, F.; Hanke, G.; Maes, T.; Matiddi, M.; Nilsson, P.; Oosterbaan, L.; Priestland, E. Harm Caused by Marine Litter: MSFD GES TG Marine Litter-Thematic Report; Publications Office of the European Union: Luxembourg, 2016; ISBN 92-79-64535-8.

37. Gregory, M.R. Accumulation and Distribution of Virgin Plastic Granules on New Zealand Beaches. N. Z. J. Mar. Freshw. Res. 1978, 12, 399-414. [CrossRef]

38. Stats, N.Z. Overseas Merchandise Trade Datasets. 2017 Imports HS10. Available online: https://www.stats.govt.nz/largedatasets/csv-files-for-download/overseas-merchandise-trade-datasets / (accessed on 27 November 2020).

39. Ivar do Sul, J.A.; Costa, M.F. Plastic Pollution Risks in an Estuarine Conservation Unit. J. Coast. Res. 2013, 65, 48-53. [CrossRef]

40. Blair, R.M.; Waldron, S.; Phoenix, V.R.; Gauchotte-Lindsay, C. Microscopy and Elemental Analysis Characterisation of Microplastics in Sediment of a Freshwater Urban River in Scotland, UK. Environ. Sci. Pollut. Res. 2019, 26, 12491-12504. [CrossRef]

41. Moore, C.J.; Lattin, G.L.; Zellers, A.F. Measuring the Effectiveness of Voluntary Plastic Industry Efforts: AMRF'S Analysis of Operation Clean Sweep. In Proceedings of the Plastic Debris Rivers to Sea Conference, Algalita Marine Research Foundation, Long Beach, CA, USA, 7-9 September 2005.

42. About Us I Plastics New Zealand. Available online: https:/ /www.plastics.org.nz/about-us (accessed on 22 November 2021).

43. Operation Clean Sweep I Plastics New Zealand. Available online: https://www.plastics.org.nz/environment/marine-litter/ operation-clean-sweep (accessed on 22 November 2021).

44. Bridson, J.H.; Patel, M.; Lewis, A.; Gaw, S.; Parker, K. Microplastic Contamination in Auckland (New Zealand) Beach Sediments. Mar. Pollut. Bull. 2020, 151, 110867. [CrossRef]

45. Clunies-Ross, P.; Smith, G.; Gordon, K.; Gaw, S. Synthetic Shorelines in New Zealand? Quantification and Characterisation of Microplastic Pollution on Canterbury's Coastlines. N. Z. J. Mar. Freshw. Res. 2016, 50, 317-325. [CrossRef]

46. Ruffell, H.; Pantos, O.; Northcott, G.; Gaw, S. Wastewater Treatment Plant Effluents in New Zealand Are a Significant Source of Microplastics to the Environment. N. Z. J. Mar. Freshw. Res. 2021, 1-17. [CrossRef]

47. Yonkos, L.T.; Friedel, E.A.; Perez-Reyes, A.C.; Ghosal, S.; Arthur, C.D. Microplastics in Four Estuarine Rivers in the Chesapeake Bay, U.S.A. Environ. Sci. Technol. 2014, 48, 14195-14202. [CrossRef] [PubMed]

48. Tibbetts, J.; Krause, S.; Lynch, I.; Sambrook Smith, G. Abundance, Distribution, and Drivers of Microplastic Contamination in Urban River Environments. Water 2018, 10, 1597. [CrossRef] 
49. Crossland, A.C. Wetland bird monitoring at the Avon-Heathcote Estuary and Bromley Oxidation Ponds, Christchurch: August 2009 to July 2010. Notornis 2013, 60, 151-157.

50. Crossland, A.C. The Avon-Heathcote Estuary and the Bromley Oxidation Ponds, Christchurch, New Zealand: An important area for waterbirds. Stilt 2010, 57, 5-10.

51. Delaney, S.; Scott, D. Waterbird Population Estimates, 4th ed.; Wetlands International: Wageningen, The Netherlands, 2006.

52. Owen, S.J. The Estuary: Where Our Rivers Meet The Sea: Christchurch's Avon-Heathcote Estuary and Brooklands Lagoon; Parks Unit, Christchurch City Council: Christchurch, New Zealand, 1992; ISBN 0-473-01595-1.

53. Hampson, S.C.; Marsden, I.D.; Roberts, C. Recreational Survey and Evaluation of Cockle (Tuaki) Resources in the Avon-Heathcote Estuary/Ihutai, Summer 2017-2018; Estuarine Research Report 47; The University of Canterbury: Christchurch, New Zealand, 2019. Available online: http:/ / www.estuary.org.nz (accessed on 18 August 2020).

54. QGIS Association. QGIS Geographic Information System. 2020. Available online: http://www.qgis.org (accessed on 2 October 2020).

55. Martin, J.; Lusher, A.; Thompson, R.C.; Morley, A. The Deposition and Accumulation of Microplastics in Marine Sediments and Bottom Water from the Irish Continental Shelf. Sci. Rep. 2017, 7, 10772. [CrossRef]

56. Hoellein, T.J.; Shogren, A.J.; Tank, J.L.; Risteca, P.; Kelly, J.J. Microplastic Deposition Velocity in Streams Follows Patterns for Naturally Occurring Allochthonous Particles. Sci. Rep. 2019, 9, 3740. [CrossRef] [PubMed]

57. Turner, A.; Wallerstein, C.; Arnold, R. Identification, Origin and Characteristics of Bio-Bead Microplastics from Beaches in Western Europe. Sci. Total Environ. 2019, 664, 938-947. [CrossRef] [PubMed]

58. Lusher, A.L.; Bråte, I.L.N.; Munno, K.; Hurley, R.R.; Welden, N.A. Is It or Isn't It: The Importance of Visual Classification in Microplastic Characterization. Appl. Spectrosc. 2020, 74, 1139-1153. [CrossRef] [PubMed]

59. Thaysen, C.; Munno, K.; Hermabessiere, L.; Rochman, C.M. Towards Raman Automation for Microplastics: Developing Strategies for Particle Adhesion and Filter Subsampling. Appl. Spectrosc. 2020, 74, 976-988. [CrossRef] [PubMed]

60. Veerasingam, S.; Saha, M.; Suneel, V.; Vethamony, P.; Rodrigues, A.C.; Bhattacharyya, S.; Naik, B.G. Characteristics, Seasonal Distribution and Surface Degradation Features of Microplastic Pellets along the Goa Coast, India. Chemosphere 2016, 159, 496-505. [CrossRef] [PubMed]

61. Cheung, P.K.; Cheung, L.T.O.; Fok, L. Seasonal Variation in the Abundance of Marine Plastic Debris in the Estuary of a Subtropical Macro-Scale Drainage Basin in South China. Sci. Total Environ. 2016, 562, 658-665. [CrossRef]

62. Hidalgo-Ruz, V.; Thiel, M. Distribution and Abundance of Small Plastic Debris on Beaches in the SE Pacific (Chile): A Study Supported by a Citizen Science Project. Mar. Environ. Res. 2013, 87-88, 12-18. [CrossRef]

63. Zhao, S.; Zhu, L.; Li, D. Microplastic in Three Urban Estuaries, China. Environ. Pollut. 2015, 206, 597-604. [CrossRef] [PubMed]

64. Vermaire, J.C.; Pomeroy, C.; Herczegh, S.M.; Haggart, O.; Murphy, M. Microplastic Abundance and Distribution in the Open Water and Sediment of the Ottawa River, Canada, and Its Tributaries. Facets 2017, 2, 301-314. [CrossRef]

65. Baldwin, A.K.; Corsi, S.R.; Mason, S.A. Plastic Debris in 29 Great Lakes Tributaries: Relations to Watershed Attributes and Hydrology. Environ. Sci. Technol. 2016, 50, 10377-10385. [CrossRef]

66. Browne, M.A.; Galloway, T.S.; Thompson, R.C. Spatial Patterns of Plastic Debris along Estuarine Shorelines. Environ. Sci. Technol. 2010, 44, 3404-3409. [CrossRef] [PubMed]

67. Macara, G.R. The Climate and Weather of Canterbury (No.68); NIWA Science and Technology Series; N.Z, NIWA National Institute of Water \& Atmospheric Research: Christchurch, New Zealand, 2016.

68. Lee, J.; Hong, S.; Song, Y.K.; Hong, S.H.; Jang, Y.C.; Jang, M.; Heo, N.W.; Han, G.M.; Lee, M.J.; Kang, D.; et al. Relationships among the Abundances of Plastic Debris in Different Size Classes on Beaches in South Korea. Mar. Pollut. Bull. 2013, 77, 349-354. [CrossRef] [PubMed]

69. Karlsson, T.M.; Arneborg, L.; Broström, G.; Almroth, B.C.; Gipperth, L.; Hassellöv, M. The Unaccountability Case of Plastic Pellet Pollution. Mar. Pollut. Bull. 2018, 129, 52-60. [CrossRef] [PubMed]

70. Claessens, M.; Meester, S.D.; Landuyt, L.V.; Clerck, K.D.; Janssen, C.R. Occurrence and Distribution of Microplastics in Marine Sediments along the Belgian Coast. Mar. Pollut. Bull. 2011, 62, 2199-2204. [CrossRef]

71. Bolton-Ritchie, L.; Main, M. Nutrient Water Quality Avon-Heathcote Estuary/Ihutai. Inputs, Concentrations and Potential Effects; Environment Canterbury Technical Report U05/71; Christchurch, New Zealand, June 2005; 84p. Available online: https: / / docs.niwa.co.nz/library/public/ECtrU05-71.pdf (accessed on 27 November 2021).

72. Vianello, A.; Boldrin, A.; Guerriero, P.; Moschino, V.; Rella, R.; Sturaro, A.; Da Ros, L. Microplastic Particles in Sediments of Lagoon of Venice, Italy: First Observations on Occurrence, Spatial Patterns and Identification. Estuar. Coast. Shelf Sci. 2013, 130, 54-61. [CrossRef]

73. Moore, S.L.; Gregorio, D.; Carreon, M.; Weisberg, S.B.; Leecaster, M.K. Composition and Distribution of Beach Debris in Orange County, California. Mar. Pollut. Bull. 2001, 42, 241-245. [CrossRef]

74. Robb, J.A. An Ecological Study of the Bromley Oxidation Ponds and Surrounding Environs. Ph.D. Thesis, The University of Canterbury, Christchurch, New Zealand, 1974.

75. Carpenter, E.J.; Anderson, S.J.; Harvey, G.R.; Miklas, H.P.; Peck, B.B. Polystyrene Spherules in Coastal Waters. Science 1972, 178, 749-750. [CrossRef]

76. Cooper, D.A.; Corcoran, P.L. Effects of Mechanical and Chemical Processes on the Degradation of Plastic Beach Debris on the Island of Kauai, Hawaii. Mar. Pollut. Bull. 2010, 60, 650-654. [CrossRef] [PubMed] 
77. Vermeiren, P.; Muñoz, C.C.; Ikejima, K. Sources and Sinks of Plastic Debris in Estuaries: A Conceptual Model Integrating Biological, Physical and Chemical Distribution Mechanisms. Mar. Pollut. Bull. 2016, 113, 7-16. [CrossRef]

78. Rios, L.M.; Moore, C.; Jones, P.R. Persistent Organic Pollutants Carried by Synthetic Polymers in the Ocean Environment. Mar. Pollut. Bull. 2007, 54, 1230-1237. [CrossRef]

79. Gadd, J.; Dudley, B.; Montgomery, J.; Whitehead, A.; Measures, R.; Plew, D. Water quality of Estuary of the Heathcote and Avon Rivers/Ihutai. Prepared for Environment Canterbury, NIWA Client Report 2020183AK; June 2020. Available online: https:/ /api.ecan.govt.nz/TrimPublicAPI/ documents/download/3899087 (accessed on 27 November 2021).

80. Mofokeng, R.P.; Glassom, D. Time Integrated Metal Accumulation on Pellets in an Industrial Harbour "Durban Harbour". Microplastics 2021, 1, 3-14. [CrossRef]

81. Rochman, C.M.; Hoh, E.; Hentschel, B.T.; Kaye, S. Long-Term Field Measurement of Sorption of Organic Contaminants to Five Types of Plastic Pellets: Implications for Plastic Marine Debris. Environ. Sci. Technol. 2013, 47, 1646-1654. [CrossRef] [PubMed]

82. Ballent, A.; Corcoran, P.L.; Madden, O.; Helm, P.A.; Longstaffe, F.J. Sources and Sinks of Microplastics in Canadian Lake Ontario Nearshore, Tributary and Beach Sediments. Mar. Pollut. Bull. 2016, 110, 383-395. [CrossRef]

83. Andrady, A.L. Persistence of Plastic Litter in the Oceans. In Marine Anthropogenic Litter; Bergmann, M., Gutow, L., Klages, M., Eds.; Springer International Publishing: New York, NY, USA, 2015; pp. 57-72. ISBN 978-3-319-16509-7.

84. Polyethylene (Low Density) LDPE, LLDPE. Available online: https://www.bpf.co.uk/plastipedia/polymers/ldpe.aspx (accessed on 22 November 2021). 